\title{
Preparation of Si-Al-N-C Ceramic Composites by Pyrolysis of Blended Precursors
}

\author{
Yusuke MORI, Takeshi UEDA, Satoshi KITAOKA* and Yoshiyuki SUGAHARA \\ Department of Applied Chemistry, School of Science and Engineering, Waseda University, 3-4-1, Ohkubo, Shinjuku-ku, Tokyo 169-8555 \\ * Japan Fine Ceramics Center, 2-4-1, Mutsuno, Atsuta-ku, Nagoya-shi 456-8587 \\ ブレンド前駆体の熱分解による Si-Al-N-C セラミックコンポジットの作製 \\ 森＼cjkstart勇介·植田武史 ·北岡 諭* 菅原義之 \\ 早稲田大学理工学部応用化学科, 169-8555 東京都新宿区大久保 3-4-1 \\ *(財)ファインセラミックスセンター, 456-8587 名古屋市熱田区六野 2-4-1
}

\begin{abstract}
Si-Al-N-C precursors have been prepared from perhydropolysilazane (PHPS) and cage-type poly (ethyliminoalane) $\left[(\text { HAINEt })_{n}\right.$; PEIA, $n$ is mainly 8] with different $\mathrm{Si} / \mathrm{Al}$ molar ratios $(\mathrm{Si} / \mathrm{Al}=3,1,1 / 3)$. Spectroscopic analysis indicates that essentially no Si-N-Al linkages form, indicating that the precursors are blended polymers. TG analysis reveals that the ceramic yields of the blended precursors up to $900^{\circ} \mathrm{C}$ are higher than those of PHPS and (HAINEt $)_{n}$, suggesting that cross-linking reactions occur during pyrolysis. Possible reactions are dehydrocoupling and radical reactions, as suggested by the results of solid-state nuclear magnetic resonance (NMR) spectroscopy. The results of solid-state NMR spectroscopy and X-ray diffraction (XRD) analysis indicate that the residue pyrolyzed at $1600^{\circ} \mathrm{C}$ contains mainly crystalline $\mathrm{AIN}, 2 \mathrm{H}$-SiC and $\beta$-SiC.
\end{abstract}

[Received February 20, 2006; Accepted April 19, 2006]

Key-words : Precursors, Ceramic-based composites, Silicon carbide, Aluminum nitride, Polysilazane

1. Introduction

Ceramic-based composites have been considered as attractive materials, since these composites generally have superior properties compared to single-component ceramics. ${ }^{1)}$ Considerable attention has been given to an aluminum nitride (AlN)-silicon carbide ( $\mathrm{SiC})$ composite because this composite exhibits many attractive properties such as high hardness, toughness, excellent resistance to oxidation and corrosion, high thermal conductively, high electrical resistance and low thermal expansion. ${ }^{2-7)}$

Pyrolytic organic-to-inorganic conversion of precursors, including inorganic and organometallic polymers, is a chemical route to non-oxide ceramics, such as nitrides and carbides of main group elements and transition metals, and ceramicbased composites. ${ }^{8)}$-14) If precursors are fusible at relatively low temperatures or soluble in common organic solvents, this route can offer significant advantages for fabrication of ceramics and ceramic-based composites with desirable shapes, including coatings and fibers. Precursors can also be applied for powder processing, as sintering aids and binders. In addition, this process could lead to ceramic-based composites with homogeneous distribution of the component elements.

Precursors for composites are commonly single-source precursors, which typically possess heterogeneous $\mathrm{M}-\mathrm{N}-\mathrm{M}^{\prime}$ and/or M-C-M' linkages. ${ }^{15), 16)}$ The advantage of singlesource precursors is the atomic-level homogeneity of their elemental compositions. In addition, a blended precursor approach to fabrication of composites can also be proposed. The blended precursors are usually prepared by simply mixing two single-component precursors. ${ }^{17)}$ If single-component precursors are miscible with each other or soluble in organic solvents, a molecular-level homogeneity can be achieved in blended precursors. A few studies have described the preparation of ceramic-based composites using the blended precursor approach. ${ }^{14), 17)}$

Perhydropolysilazane (PHPS) possessing Si-N backbones is a soluble precursor for $\mathrm{Si}-\mathrm{N}-\mathrm{C}$-based materials that exhibits a relatively high ceramic yield. ${ }^{18)}$ As soluble precursors exhibiting moderate ceramic yields for AlN, poly (alkyliminoalane $) \mathrm{s}\left[(\mathrm{HAlNR})_{n}\right.$; PIAs, $\mathrm{R}=$ alkyl $]$, cage-type oligomers possessing Al-N backbones, can be proposed. ${ }^{19)}$ We have prepared AlN by pyrolysis of cage-type PIAs, poly (ethyliminoalane $)\left[(\mathrm{HAlNEt})_{n}\right.$; PEIA, $n$ is mainly 8$]$ and poly (isopropyliminoalane) [( $\left.\mathrm{HAlN}^{i} \mathrm{Pr}\right)_{n}$; PIPIA, $n$ is mainly 6] and reported that the ceramic yield of PEIA was higher than that of PIPIA. ${ }^{20)-25)} \mathrm{Si}-\mathrm{Al}-\mathrm{N}-\mathrm{C}$ ceramic composites can therefore be obtained easily by pyrolysis of a precursor that is prepared by blending PHPS and PEIA.

Here we report the preparation of $\mathrm{Si}-\mathrm{Al}-\mathrm{N}-\mathrm{C}$ ceramic composites by pyrolysis of blended precursors that were synthesized simply by mixing PHPS with PEIA and that possess essentially no $\mathrm{Si}-\mathrm{N}-\mathrm{Al}$ linkages. We focus on the pyrolytic organic-to-inorganic conversion of the blended precursors, investigated by solid-state nuclear magnetic resonance (NMR) spectroscopy and X-ray diffraction (XRD) analysis.

\section{Experimental}

All the manipulations were performed under a protective nitrogen atmosphere using the standard Schlenk technique or a nitrogen-filled glove box. ${ }^{26)}$ Toluene (Kanto Chemical) and $p$-xylene (Wako Pure Chemical Industries) were distilled over sodium and benzophenone under a nitrogen atmosphere. PHPS (Clariant Japan, N-N310, with an average molecular mass of 974) was used as received. The preparation procedure for PEIA was described elsewhere. ${ }^{20)}$

\subsection{Preparation of the blended precursors}

The blended precursors were prepared from PHPS and PEIA with different $\mathrm{Si} / \mathrm{Al}$ ratios $(\mathrm{Si} / \mathrm{Al}=3,1,1 / 3$, hereinafter abbreviated as SA31, SA11 and SA13, respectively). The preparation of the blended precursor (SA11) is described below as a representative example, since the other precursors were prepared in a similar manner. The reaction was conducted in a two-necked round-bottomed flask equipped with a gas inlet tube and a glass stopper. The apparatus was charged with 
PEIA $(2.15 \mathrm{~g}$ ) and $p$-xylene. PHPS (1.38 g) in $p$-xylene was added to this solution by means of a stainless cannula. After stirring at $30^{\circ} \mathrm{C}$ for one hour, $p$-xylene was removed from this solution by trap-to-trap distillation under reduced pressure to yield a white soluble solid.

\subsection{Pyrolysis of the blended precursors}

For pyrolysis at $200-400^{\circ} \mathrm{C}$, SA11 was placed on a BN boat in a quartz tube under an argon atmosphere and pyrolyzed at the desired temperature with no holding time. The heating and cooling rate was $5^{\circ} \mathrm{C} / \mathrm{min}$. For pyrolysis at $1600^{\circ} \mathrm{C}$, SA11 was placed on a $\mathrm{BN}$ boat in an alumina tube under an argon atmosphere. The heating rate was $10^{\circ} \mathrm{C} / \mathrm{min}$ from room temperature to $200^{\circ} \mathrm{C}$ and $5^{\circ} \mathrm{C} / \mathrm{min}$ from 200 to $1600^{\circ} \mathrm{C}$. The temperature was maintained at $1600^{\circ} \mathrm{C}$ for $2 \mathrm{~h}$, and the pyrolyzed residue was then cooled to room temperature at $5^{\circ} \mathrm{C} / \mathrm{min}$.

2.3 Characterization of the blended precursors and the pyrolyzed residues

The blended precursors were characterized by nuclear magnetic resonance (NMR) spectroscopy (JEOL, JNMLambda 500). The ${ }^{27} \mathrm{Al} \mathrm{NMR}(130.20 \mathrm{MHz})$ spectra of the precursors were recorded on the same apparatus using $\left[\mathrm{Al}\left(\mathrm{H}_{2} \mathrm{O}\right)_{6}\right]^{3+}(0 \mathrm{ppm})$ as an external standard. Thermogravimetry (TG, Perkin-Elmer, TGA-7) was performed at a heating rate of $10^{\circ} \mathrm{C} / \mathrm{min}$ under flowing argon up to $900^{\circ} \mathrm{C}$.

The pyrolyzed residues were characterized by solid-state NMR spectroscopy (JEOL, NM-GSX 400) and X-ray diffraction (XRD, Rigaku, Rint-2500) analysis. For the residues pyrolyzed at $200-400^{\circ} \mathrm{C}$, the solid-state ${ }^{29} \mathrm{Si} \mathrm{NMR}$ $(79.43 \mathrm{MHz})$ spectra of the pyrolyzed residues were obtained with cross polarization and magic angle spinning (CP/MAS) techniques. The residues were packed in sample tubes in a nitrogen-filled glove box, and kept under nitrogen flow during the measurements. Five hundred scans were accumulated with a pulse delay of $5 \mathrm{~s}$ and a spinning rate of $7 \mathrm{kHz}$. For the residue pyrolyzed at $1600^{\circ} \mathrm{C}$, the solid-state ${ }^{27} \mathrm{Al}$ and ${ }^{29} \mathrm{Si}$ NMR spectra of the pyrolyzed residue were recorded on the same instrument with the MAS technique only. Five hundred scans were accumulated with a pulse delay of $100 \mathrm{~s}\left({ }^{29} \mathrm{Si}\right)$ or $1 \mathrm{~s}$ $\left({ }^{27} \mathrm{Al}\right)$ and a spinning rate of $7 \mathrm{kHz}\left({ }^{29} \mathrm{Si}\right)$ or $9 \mathrm{kHz}\left({ }^{27} \mathrm{Al}\right)$. The XRD pattern of the pyrolyzed residue was obtained using monochromated $\mathrm{Cu} \mathrm{K} \alpha$ radiation.

\section{Results and discussions}

3.1 Preparation of soluble $\mathrm{Si}-\mathrm{Al}-\mathrm{N}-\mathrm{C}$ precursors by a blending technique

The ${ }^{27} \mathrm{Al}$ NMR spectra of the blended precursors show one signal centered at $135 \mathrm{ppm}$ assignable to the $\mathrm{H} A l \mathrm{~N}_{3}$ environment. ${ }^{19)}$ These chemical shifts in the ${ }^{27} \mathrm{Al} \mathrm{NMR} \overline{\text { spectra of the }}$ blended precursors are very similar to that of PEIA. It should be noted that no other signals are observed in the ${ }^{27} \mathrm{Al} \mathrm{NMR}$ spectra.

The structures of the blended precursors are discussed below. PHPS has reactive $\mathrm{SiH}$ and $\mathrm{NH}$ bonds, and PEIA has reactive $\mathrm{AlH}$ bonds. In the preparation of aluminum-modified polysilazanes, $\mathrm{NH}$ bonds and $\mathrm{AlH}$ bonds can undergo dehydrocoupling to form new Al-N bonds. ${ }^{27)}$ In our previous work, we found that the precursor for $\mathrm{Al}-\mathrm{Si}-\mathrm{N}-\mathrm{C}$ ceramic composites possessed Al-N-Si linkages formed via dehydrocoupling between the $\mathrm{NH}$ bonds in cyclosilazane $[\mathrm{Me}(\mathrm{H})$ $\mathrm{SiNH}]_{m}$ and the $\mathrm{AlH}$ bonds in a cage-type oligomer $\left(\text { HAlN }^{i} \mathrm{Pr}\right)_{n}{ }^{28)}{ }^{29)}$ The ${ }^{27} \mathrm{Al}$ NMR spectrum of this precursor exhibited a broad signal at $100 \mathrm{ppm}^{28)}{ }^{29)}$ assignable to the $A l \mathrm{~N}_{4}$ environment, ${ }^{30}$ ) which was formed by dehydrocoupling between the $\mathrm{NH}$ bonds and the $\mathrm{AlH}$ bonds in the $\mathrm{H} A l \mathrm{~N}_{3}$ environment. Since only the $\mathrm{H} A l \mathrm{~N}_{3}$ resonance at $135 \mathrm{ppm}$ is

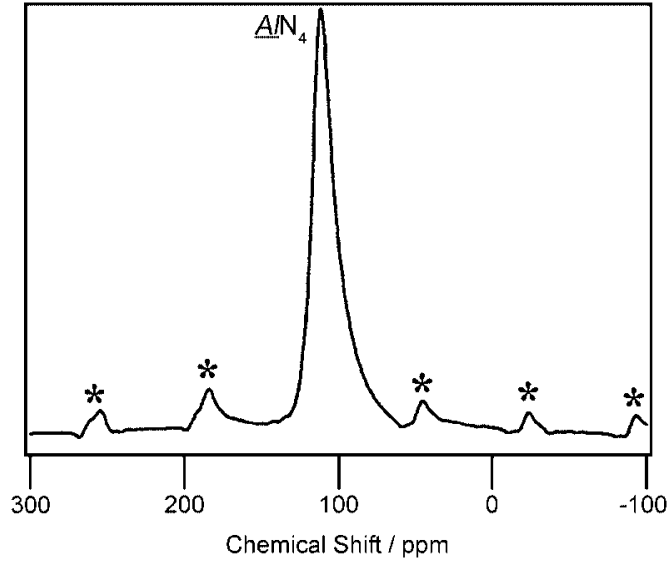

Fig. 1. Solid-state ${ }^{27} \mathrm{Al} \mathrm{NMR}$ spectra of SA11 pyrolyzed at $1600^{\circ} \mathrm{C}$. The signals marked by asterisks are spinning side bands.

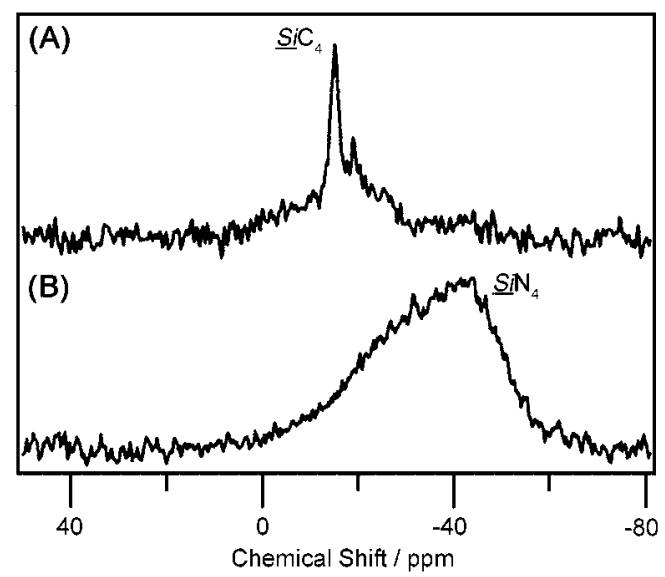

Fig. 2. Solid-state ${ }^{29}$ Si NMR spectra of SA11 pyrolyzed at (A) 1600 ${ }^{\circ} \mathrm{C}$ and (B) $1000^{\circ} \mathrm{C}$.

observed and no $A l \mathrm{~N}_{4}$ resonance at $100 \mathrm{ppm}$ is observed in the ${ }^{27} \mathrm{Al} \mathrm{NMR}$ spectra of the blended precursors, dehydrocoupling between the NH bonds in PHPS and the AlH bonds in PEIA occurs only to a very limited extent; essentially no Al-N-Si linkages are formed during the preparation of the blended precursors. In the preparation of precursors possessing Al-N-Si linkages, at least one of the starting compounds must be a compound with a relatively low molecular mass such as tetrakis (methylaminosilane); $\mathrm{Si}\left(\mathrm{NHCH}_{3}\right)_{4}$, cyclosilazane, Lewis-base adduct of alane $\left.\left(\mathrm{H}_{3} \mathrm{Al} \cdot \mathrm{NMe}_{3}\right)\right],{ }^{27)-29)}$ while both PHPS and PEIA are compounds with a relatively high molecular mass or oligometric compounds. Thus, it is reasonable to assume that the occurrence of dehydrocoupling is limited during the preparation of precursors because of the steric hindrance.

3.2 Characterizations of the residue pyrolyzed at $1600^{\circ} \mathrm{C}$

Figure 1 shows the solid-state ${ }^{27} \mathrm{Al}$ NMR spectrum of SA11 pyrolyzed at $1600^{\circ} \mathrm{C}$. The solid-state ${ }^{27} \mathrm{Al} \mathrm{NMR}$ spectrum exhibits one signal at $110 \mathrm{ppm}$, which is assignable to the $A l \mathrm{~N}_{4}$ environment. ${ }^{31)}$ It is worth noting that this signal corresponds to the chemical shift for AlN. ${ }^{31)}$ Figure 2 shows the solid-state ${ }^{29} \mathrm{Si}$ NMR spectrum of the residues pyrolyzed of SA11. The solid-state ${ }^{29} \mathrm{Si}$ NMR spectrum of SA11 pyrolyzed at $1600^{\circ} \mathrm{C}$ (Fig. 2A) exhibits two signals at -16 and $-20 \mathrm{ppm}$ and two shoulders centered at $\sim-14 \mathrm{ppm}$ and $\sim-23 \mathrm{ppm}$, which are 


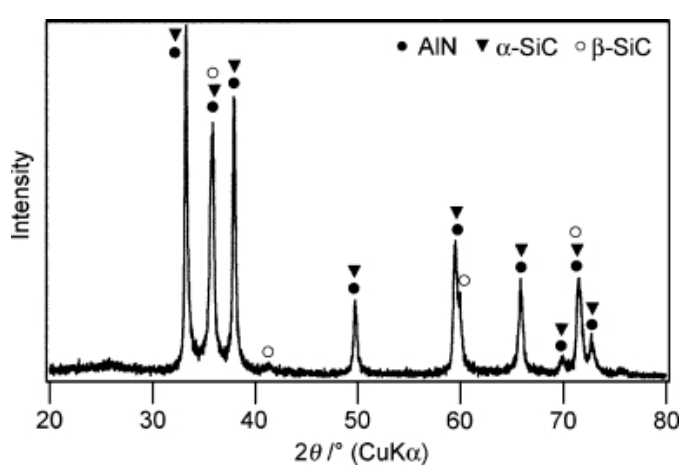

Fig. 3. XRD pattern of SA11 pyrolyzed at $1600^{\circ} \mathrm{C}$.

attributable to the $\mathrm{SiC}_{4}$ environments. ${ }^{32)-35)}$ The $\mathrm{SiC}_{4}$ resonances at $-16 \mathrm{ppm}$ seem to be close to the reported chemical shifts for $\beta$-SiC. ${ }^{32)}$ In terms of the resonances of the $\mathrm{SiC}_{4}$ environments in $\alpha$-SiC, which has various polytypes (e.g., $\overline{2} H$, $4 H, 6 H, 15 R$, etc. ), the signal positions depend on the crystal structures. The ${ }^{29} \mathrm{Si} \mathrm{NMR}$ spectrum of $2 \mathrm{H}$-SiC exhibited only one signal at $-20 \mathrm{ppm} .{ }^{33)}$ In the ${ }^{29} \mathrm{Si} \mathrm{NMR}$ spectra of $6 H$ and $15 R$ polytypes, three $\mathrm{SiC}_{4}$ resonances were observed at $\sim-14.5 \mathrm{ppm}, \sim-20.5 \mathrm{ppm}$ and $\sim-24.5 \mathrm{ppm} .{ }^{33)-35)}$ The intensity ratios (high to low frequency) were $1: 1: 1(6 H)$ and $1: 2: 2(15 R)$. In the spectrum of $4 H$ polytypes, two $\mathrm{SiC}_{4}$ resonances were observed at $-19.7 \mathrm{ppm}$ and $-22.5 \mathrm{ppm}$ and the intensity ratio was $1: 1 .{ }^{33)}$ In the spectrum of SA11 pyrolyzed at $1600^{\circ} \mathrm{C}$, an intense $\mathrm{SiC}_{4}$ resonance is observed at $-20 \mathrm{ppm}$, and the signal at $-\overline{20} \mathrm{ppm}$ can therefore be attributed to the $\mathrm{SiC}_{4}$ environment in $2 \mathrm{H}$-SiC. The presence of shoulders at $\sim-14 \mathrm{ppm}$ and $\sim-23 \mathrm{ppm}$ suggests that the residue could contain small amounts of $4 H, 6 H$ and/or $15 R$ polytypes.

Figure 3 shows the XRD pattern of SA11 pyrolyzed at $1600^{\circ} \mathrm{C}$. In the XRD pattern of the residue, the overlapping reflections are assignable to $\mathrm{AlN}, \alpha-\mathrm{SiC}$ and $\beta$-SiC, which are identified by the aforementioned results for the solid-state NMR. It is therefore concluded that the residue of SA11 pyrolyzed at $1600^{\circ} \mathrm{C}$ mainly possesses crystalline $\mathrm{AlN}, 2 \mathrm{H}-\mathrm{SiC}$ and $\beta$-SiC. The minor crystalline phases in the residue may be $4 H$, $6 H$ and/or $15 R$ polytypes.

With pyrolysis of PHPS, which possesses the Si-N backbone, the $\mathrm{Si}_{3} \mathrm{~N}_{4}$ formation generally occurs. ${ }^{18), 36)-40)}$ The solid-state ${ }^{29} \mathrm{Si} \mathrm{NMR}$ spectrum of SA11 pyrolyzed at $1000^{\circ} \mathrm{C}$ (Fig. 2B) exhibits a broad signal at $\sim-44 \mathrm{ppm}$, which is assignable to the $\mathrm{SiN}_{4}$ environment, ${ }^{30)}$ and no $\mathrm{Si}_{3} \mathrm{~N}_{4}$ reflection is observed in the XRD pattern of $\mathbf{S A 1 1}$ pyrolyzed at $1000^{\circ} \mathrm{C}$. These results suggest the presence of amorphous $\mathrm{Si}_{3} \mathrm{~N}_{4}$ in the residue pyrolyzed at $1000^{\circ} \mathrm{C}$. As described above, the results for the solid-state ${ }^{29} \mathrm{Si} \mathrm{NMR}$ spectrum and XRD pattern indicate the presence of crystalline $\mathrm{SiC}$ in the residue pyrolyzed at $1600^{\circ} \mathrm{C}$. Based on thermodynamic considerations, the transformation from $\mathrm{Si}_{3} \mathrm{~N}_{4}$ into $\mathrm{SiC}$ can occur above $1440^{\circ} \mathrm{C}$ via the following reaction: ${ }^{41}$

$$
\mathrm{Si}_{3} \mathrm{~N}_{4}+3 \mathrm{C} \longrightarrow 3 \mathrm{SiC}+2 \mathrm{~N}_{2}
$$

Thus, it is suggested that the formation of crystalline $\mathrm{SiC}$ is due to this reaction, and that the residue pyrolyzed at $1000^{\circ} \mathrm{C}$ appears to contain amorphous $\mathrm{Si}_{3} \mathrm{~N}_{4}$ and free carbon.

3.3 Pyrolytic behavior of the blended precursors

Figure 4 shows the TG curves of the blended precursors, PHPS and PEIA. The ceramic yields of SA31, SA11 and SA13, up to $900^{\circ} \mathrm{C}$ under an Ar atmosphere are 87.5, 80.3 and

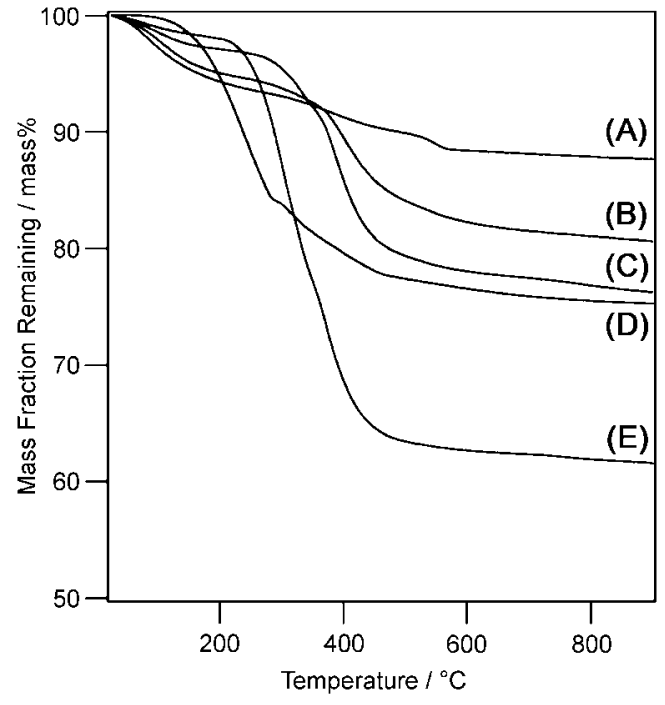

Fig. 4. TG curves of (A) SA31, (B) SA11, (C) SA13, (D) PHPS and (E) PEIA.

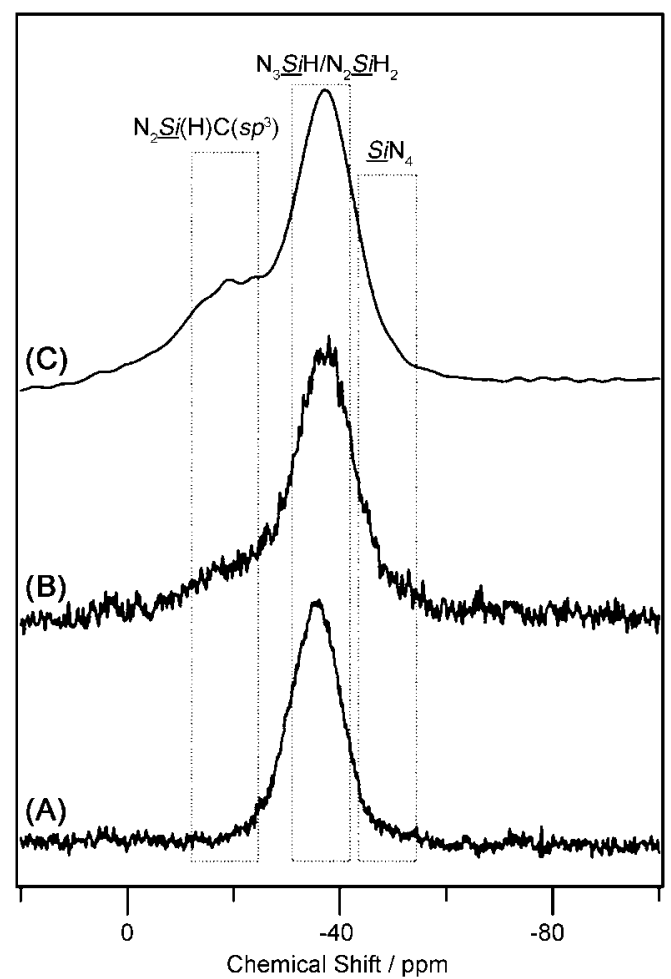

Fig. 5. Solid-state ${ }^{29} \mathrm{Si}$ NMR spectra of SA11 pyrolyzed at (A) $200^{\circ} \mathrm{C}$, (B) $300^{\circ} \mathrm{C}$ and $(\mathrm{C}) 400^{\circ} \mathrm{C}$.

76.0 mass $\%$, respectively. These ceramic yields are higher than those of PHPS (75.3 mass\%) and PEIA (61.1 mass\%), although essentially no Al-N-Si linkage between the two starting precursors is formed during the preparation of the blended precursors. This observation seems to suggest that cross-linking reactions progress during pyrolysis.

Spectroscopic characterizations of the residues pyrolyzed at $200-400^{\circ} \mathrm{C}$ (SA11) were therefore carried out in order to investigate the pyrolytic process of the blended precursors in detail. Figure 5 shows the solid-state ${ }^{29} \mathrm{Si}$ NMR spectra of the 
Below $\sim 300^{\circ} \mathrm{C}$

(A) $=\mathrm{N}:+\mathrm{CH}_{3} \mathrm{CH}_{2}-\mathrm{N} \rightarrow=\mathrm{NH}+\mathrm{CH}_{2}=\mathrm{CH}_{2}+\mathrm{N}=$ $300-650^{\circ} \mathrm{C}$

(B) $=\mathrm{N}-\mathrm{CH}_{2} \mathrm{CH}_{3} \rightarrow=\mathrm{NH}+\mathrm{CH}_{2}=\mathrm{CH}_{2}$

(C) $=\mathrm{N}-\mathrm{CH}_{2} \mathrm{CH}_{3} \rightarrow=\mathrm{N}^{\cdot}+\mathrm{CH}_{2} \mathrm{CH}_{3}$

$\cdot \mathrm{CH}_{2} \mathrm{CH}_{3} \rightarrow \mathrm{H} \cdot \mathrm{CH}_{2}=\mathrm{CH}_{2}$

Scheme 1. Possible reactions during pyrolysis of poly (ethyliminoalane) (PEIA).

residue pyrolyzed at $200-400^{\circ} \mathrm{C}$. The residue at $200^{\circ} \mathrm{C}$ exhibits one broad signal at $\sim-37 \mathrm{ppm}$, assignable to the $\mathrm{N}_{3} \mathrm{SiH} /$ $\mathrm{N}_{2} \mathrm{SiH}_{2}$ environments. ${ }^{42), 43)}$ As the temperature increases, shoulders appear at $\sim-44 \mathrm{ppm}$ and at $\sim-20 \mathrm{ppm}$. These shoulders are attributable to the $\mathrm{SiN}_{4}{ }^{30)}$ and $\mathrm{N}_{2} \mathrm{Si}(\mathrm{H}) \mathrm{C}\left(s p^{3}\right)$ environments, ${ }^{44)-47)}$ respectively. In the ${ }^{29} \mathrm{Si}$ NMR spectrum at $400^{\circ} \mathrm{C}$, the $\mathrm{N}_{2} \mathrm{Si}(\mathrm{H}) \mathrm{C}\left(s p^{3}\right)$ resonance is clearly observed.

Based on these observations, the possible pyrolysis mechanism can be discussed. During pyrolysis of PEIA below $\sim 300^{\circ} \mathrm{C}$, the heterolytic cleavage of an $\mathrm{Al}-\mathrm{N}$ bond in PEIA seems to occur to form nitrogen terminals $(=\mathrm{N}:)$. The nitrogen terminals subsequently attack the ethyl groups in PEIA to lead to the formation of new NH bonds (Scheme 1A). ${ }^{25)}$ This reaction can occur continuously because of regeneration of the nitrogen terminals. From $\sim 300^{\circ} \mathrm{C}$ to $\sim 650^{\circ} \mathrm{C}$, new NH bonds should form via the concerted $\beta$-elimination mechanism (Scheme 1B). ${ }^{25), 48)}$ Since the $\mathrm{SiN}_{4}$ resonance is observed at $\sim-44 \mathrm{ppm}$ in the ${ }^{29} \mathrm{Si} \mathrm{NMR}$ spectrum of the residue pyrolyzed at $400^{\circ} \mathrm{C}$, the $\mathrm{SiH}$ bonds in PHPS moiety appear to react with the $\mathrm{NH}$ bonds to form new $\mathrm{Si}-\mathrm{N}$ bonds. In the pyrolysis of aluminum- or boron-modified polysilazane, dehydrocoupling between the $\mathrm{SiH}$ and the $\mathrm{NH}$ bonds occurred to form new $\mathrm{Si}-\mathrm{N}$ bonds in this temperature range. ${ }^{49)-51)}$ It is therefore assumed that a possible reaction during pyrolysis up to $400^{\circ} \mathrm{C}$ is dehydrocoupling between the $\mathrm{SiH}$ bonds in PHPS moiety and the NH bonds in PHPS moiety and/or the newly-formed $\mathrm{NH}$ bonds in PEIA moiety:

$$
\equiv \mathrm{SiH}+\mathrm{HN}=\longrightarrow \equiv \mathrm{Si}-\mathrm{N}=+\mathrm{H}_{2}
$$

The formation of ethylene during pyrolysis of PEIA from $\sim 300^{\circ} \mathrm{C}$ to $\sim 650^{\circ} \mathrm{C}$ upon the homolytic cleavage of $\mathrm{C}-\mathrm{N}$ bonds in $=\mathrm{NEt}$ groups involves the formation of radicals $\left(=\mathrm{N}^{\bullet}, \mathrm{R}^{\cdot}\right)$ and the subsequent $\beta$-elimination of a hydrogen radical $\left(\mathrm{H}^{\bullet}\right)$ (Scheme $\left.1 \mathrm{C}\right) .{ }^{25), 52)}$ The radicals $\left(\mathrm{R}^{\bullet}\right)$ can react with $\mathrm{SiH}$ bonds to form silicon radicals $\left(\mathrm{Si}^{\bullet}\right)$ via hydrogen abstraction. ${ }^{53)}{ }^{54)}$ (Scheme 2A) In the ${ }^{29} \mathrm{Si}$ NMR spectra of the residues pyrolyzed at $300-400^{\circ} \mathrm{C}, \mathrm{N}_{2} \mathrm{Si}(\mathrm{H}) \mathrm{C}\left(s p^{3}\right)$ resonances are observed at $-20 \mathrm{ppm}$, suggesting the presence of new $\mathrm{Si}-\mathrm{C}$ bonds. For the formation of new $\mathrm{Si}-\mathrm{C}$ bonds, a possible mechanism that involves a reaction between the silicon radicals $\left(\mathrm{Si}^{\bullet}\right)$ and ethylene (Scheme 2B) can be proposed. ${ }^{53), 54)}$ Based on these results, possible reactions occurring during pyrolysis are dehydrocoupling between the $\mathrm{SiH}$ and $\mathrm{NH}$ bonds and radical reactions.

\section{Conclusions}

Soluble blended precursors for $\mathrm{Si}-\mathrm{Al}-\mathrm{N}-\mathrm{C}$ ceramic composites have been prepared from perhydropolysilazane (PHPS) and poly (ethyliminoalane) (PEIA). The ceramic yields of the blended precursors up to $900^{\circ} \mathrm{C}$ are higher than those of the starting precursors, a result which can be ascribed to cross-
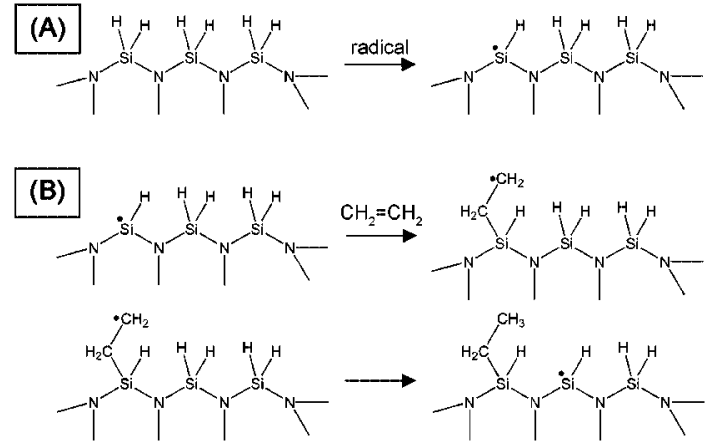

Scheme 2. Possible mechanism of the formation of $\mathrm{Si}-\mathrm{C}$ bonds $(\mathrm{R}$ $=\mathrm{Et}$ ).

linking reactions, possibly including dehydrocoupling and radical reactions during pyrolysis. The solid-state NMR spectra and XRD pattern indicate that the residue pyrolyzed at $1600^{\circ} \mathrm{C}$ contains mainly crystalline AlN, $2 H$-SiC and $\beta$-SiC. These results suggest that the precursors prepared by blending PHPS and PEIA can be considered to serve as precursors for $\mathrm{Si}-\mathrm{Al}-\mathrm{N}-\mathrm{C}$ ceramic composites.

Acknowledgements The authors gratefully thank Prof. Kazuyuki Kuroda, Department of Applied Chemistry at Waseda University, for valuable discussion. This work was supported by 21COE "Practical Nano-Chemistry" from MEXT, Japan.

\section{References}

1) Chawla, K., "Ceramic Matrix Composites," Chapman and Hall, London, U. K. (1993).

2) Werdecker, W. and Aldinger, F., IEEE, Trans. Compon., Hybrids, Manuf. Technol., Vol. CHMT-7, pp. 399-404 (1984).

3) Liao, B., Li, Y. and Lu, Y., J. Mater. Chem., Vol. 3, pp. 117-127 (1993).

4) Selvaduray, G. and Sheet, L., Mater. Sci. Technol., Vol. 9, pp. 463-473 (1993).

5) Dobson, M. M., "Silicon Carbide Alloys;" In Research Reports in Materials Science, Ed. by Evans, P. E., The Parthenon Press, U.K. (1986) pp. 1-132.

6) Landon, M. and Thevenot, F., Ceram. Int., Vol. 17, pp. 97-110 (1991).

7) Unni, C. K. and Gordon, D. E., J. Mater. Sci., Vol. 30, pp. 1173-1179 (1995).

8) Wynee, K. J. and Rice, R. W., Ann. Rev. Mater. Sci., Vol. 14, pp. 297-334 (1984).

9) Pouskouleli, G., Ceram. Int., Vol. 15, pp. 213-229 (1989).

10) Narula, C. K., "Ceramic Precursor Technology and Its Applications," Marcel Dekker, N. Y. (1995).

11) Walker, Jr., B. E., Rice, R. W., Becher, P. F., Bender, B. A. and Coblenz, W. S., Am. Ceram. Soc. Bull., Vol. 62, pp. 916-923 (1983).

12) Baldus, H. -P. and Jansen, M., Angew. Chem. Int. Ed. Engl., Vol. 36, pp. 328-343 (1997).

13) Bill, J. and Aldinger, F., Adv. Mater., Vol. 7, pp. 775-787 (1995).

14) Paine, R. T., Janik, J. F. and Fan, M., Polyhedron, Vol. 13, pp. 1225-1232 (1994).

15) Riedel, R., Kienzle, A., Dressler, W., Ruwisch, L., Bill, J. and Aldinger, F., Nature (London), Vol. 382, pp. 796-798 (1996).

16) Weinmann, M., Schumacher, J., Kummer, H., Prinz, S., Peng, J., Seifert, H. J., Christ, M., Müller, K., Bill, J. and Aldinger, F., Chem. Mater., Vol. 12, pp. 623-632 (2000).

17) Interrante, L. V., Hurley, Jr., W. J., Schmidt, W. R., Kwon, D., Doremus, R. H., Marchetti, P. S. and Maciel, G. E., Ceram. Trans., Vol. 19, pp. 3-17 (1991).

18) Kawamura, N. and Isoda, T., JETI, Vol. 38, pp. 104-108 
(1990).

19) Cesari, M. and Cucinella, S., "Aluminum-Nitrogen Ring and Cages;" in The Chemistry of Inorganic Homo- and Heterocycles, Ed. by Sowerby, D. B. and Haiduc, I., Academic Press, London, U.K. (1987) pp. 167-190.

20) Koyama, S., Takeda, H., Saito, Y., Sugahara, Y. and Kuroda, K., J. Mater. Chem., Vol. 6, pp. 1055-1058 (1996).

21) Sugahara, Y., Omura, T., Tanegashima, O., Kuroda, K. and Kato, C., J. Ceram. Soc. Japan, Vol. 100, pp. 101-103 (1992).

22) Saito, Y., Koyama, S., Sugahara, Y. and Kuroda, K., J. Ceram. Soc. Japan, Vol. 104, pp. 143-145 (1996).

23) Sugahara, Y., Koyama, S. and Kuroda, K., Key Eng. Mater., Vol. 159-160, pp. 77-82 (1999).

24) Saito, Y., Sugahara, Y. and Kuroda, K., J. Am. Ceram. Soc., Vol. 83, pp. 2436-2440 (2000).

25) Koyama, S., Takeda, H., Tsugoshi, T., Watari, K. and Sugahara, Y., J. Ceram. Soc. Japan, Vol. 114, pp. 563-566 (2006).

26) Shriver, D. F. and Drezdzon, M. A., "The Manipulation of AirSensitive Compounds," 2nd ed., Wiley-Interscience, New York (1986).

27) Löffelholz, J. and Jansen, M., Adv. Mater., Vol. 7, pp. 289-292 (1995).

28) Koyama, S., Nakashima, H., Sugahara, Y. and Kuroda, K., Chem. Lett., pp. 191-192 (1998).

29) Nakashima, H., Koyama, S., Kuroda, K. and Sugahara, Y., J. Am. Ceram. Soc., Vol. 85, pp. 59-64 (2002).

30) Verdecia, G., O'Brien, K. L., Schmidt, W. R. and Apple, T. M., Chem. Mater., Vol. 10, pp. 1003-1009 (1998).

31) Butler, N. D., Dupree, R. and Lewis, M. H., J. Mater. Sci. Lett., Vol. 3, pp. 469-470 (1984).

32) Carduner, K. R., Shinozaki, S. S., Rokosz, M. J., Peters, C. R. and Whalen, T. J., J. Am. Ceram. Soc., Vol. 73, pp. 2281-2286 (1990).

33) Apperley, D. C., Harris, R. K., Marshall, G. L. and Thompson, D. P., J. Am. Ceram. Soc., Vol. 74, pp. 777-782 (1991).

34) Hartman, J. S., Richardson, M. F., Sherriff, B. L. and Winsborrow, B. G., J. Am. Chem. Soc., Vol. 109, pp. 60596067 (1987).

35) Guth, J. R. and Petuskey, W. T., J. Phys. Chem., Vol. 91, pp. 5361-5364 (1987).

36) Funayama, O., Arai, M., Tashiro, Y., Aoki, H., Suzuki, T., Tamura, K., Kaya, H., Nishi, H. and Isoda, T., J. Ceram. Soc.
Japan (Seramikkusu Ronbunshi), Vol. 98, pp. 104-107 (1990).

37) Yokoyama, Y., Nanba, T., Yasui, I., Kaya, H., Maeshima, T. and Isoda, T., J. Am. Ceram. Soc., Vol. 74, pp. 654-657 (1991).

38) Funayama, O., Tashiro, Y., Kamo, A., Okumura, M. and Isoda, T., J. Mater. Sci., Vol. 29, pp. 4883-4888 (1994).

39) Matsuo, H., Funayama, O., Kato, T., Kaya, H. and Isoda, T., J. Ceram. Soc. Japan, Vol. 102, pp. 409-413 (1994).

40) Iwamoto, Y., Völger, W., Kroke, E. and Riedel, R., J. Am. Ceram. Soc., Vol. 84, pp. 2170-2178 (2001).

41) Gabriel, A. O., Riedel, R., Dressler, W., Reichert, S., Gervais, C., Maquet, J. and Babonneau, F., Chem. Mater., Vol. 11, pp. 412-420 (1999).

42) Funayama, O., Kato, T., Tashiro, Y. and Isoda, T., J. Am. Ceram. Soc., Vol. 76, pp. 717-723 (1993).

43) Funayama, O., Nakahara, H., Okoda, M., Okumura, M. and Isoda, T., J. Mater. Sci., Vol. 30, pp. 410-416 (1995).

44) Kleebe, H. -J., Störmer, H., Trassl, S. and Ziegler, G., Appl. Organomet. Chem., Vol. 15, pp. 858-866 (2001).

45) Yive, N. S. C. K., Corriu, R., Leclercq, D., Mutin, P. H. and Vioux, A., New J. Chem., Vol. 15, pp. 85-92 (1991).

46) Mocaer, D., Pailler, R., Naslain, R., Richard, C., Pillot, J. P., Dunogues, J., Gerardin, C. and Taulelle, F., J. Mater. Sci., Vol. 28, pp. 2615-2631 (1993).

47) Seitz, J., Bill, J., Egger, N. and Aldinger, F., J. Eur. Ceram. Soc., Vol. 16, pp. 885-891 (1996).

48) Liu, Y., Treadwell, D. R., Kannisto, M. R., Mueller, B. L. and Laine, R. M., J. Am. Ceram. Soc., Vol. 80, pp. 705-716 (1997).

49) Berger, F., Weinmann, M., Aldinger, F. and Müller, K., Chem. Mater., Vol. 16, pp. 919-929 (2004).

50) Schumacher, J., Berger, F., Weinmann, M., Bill, J., Aldinger, F. and Müller, K., Appl. Organomet. Chem., Vol. 15, pp. 809-819 (2001).

51) Mori, Y., Kumakura, Y. and Sugahara, Y., J. Organomet. Chem., submitted.

52) Burns, G. T., Angelotti, T. P., Hanneman, L. F., Chandra, G. and Moore, J. A., J. Mater. Sci., Vol. 22, pp. 2609-2614 (1987).

53) Linford, M. R. and Chidsey, C. E. D., J. Am. Chem. Soc., Vol. 115, pp. 12631-12632 (1993).

54) Boukherroub, R., Morin, S., Bensebaa, F. and Wayner, D. D. M., Langmuir, Vol. 15, pp. 3831-3835 (1999). 